\title{
RANCANG BANGUN SISTEM PENDUKUNG KEPUTUSAN SELEKSI TENAGA KERJA BERBASIS WEB MENGGUNAKAN METODE SIMPLE ADDITIVE WEIGHTING PADA PT. SOLUSI LINTAS DATA CABANG BALI
}

\author{
M. A. Fermanta ${ }^{1}$, I M. A. Suyadnya ${ }^{2}$, N. M. A. E. D. Wirastuti ${ }^{3}$
}

\begin{abstract}
PT. Solusi Lintas Data Bali is a growing company which is engaged in the field of internet service providers. The role of qualified human resources or employees greatly affect the future of the company. At PT. Solusi Lintas Data Bali, the selection process of new employees is still using conventional methods and not computerized. This causes the selection process takes a long time considering the high number of applicants. One of the solutions to overcome these problems is to build a decision support system. Decision support system built web based and uses Simple Additive Weighting method (SAW). Results of the system using SAW method is the ranking of applicants with the highest rank to the lowest rank. The results of this ranking, become a recommendation for the company in determining the prospective employee who will be accepted.
\end{abstract}

Intisari-PT. Solusi Lintas Data Cabang Bali adalah perusahaan berkembang yang bergerak dalam bidang jasa penyedia layanan internet, dimana peranan sumber daya manusia atau tenaga kerja yang baik dan berkualitas sangat mempengaruhi masa depan perusahaan. Pada PT. Solusi Lintas Data Cabang Bali, proses seleksi calon tenaga kerja masih menerapkan metode konvensional dan tidak dilakukan secara komputerisasi. Hal ini menyebabkan proses seleksi penerimaan tenaga kerja membutuhkan waktu yang cukup lama mengingat banyaknya jumlah pelamar. Salah satu cara untuk mengatasi permasalahan tersebut adalah dengan membangun suatu sistem pendukung keputusan. Sistem pendukung keputusan yang dibangun berbasis web dan menggunakan metode Simple Additive Weighting (SAW). Hasil dari proses sistem menggunakan metode SAW adalah perangkingan dari pelamar dengan rangking tertinggi sampai dengan rangking terendah. Hasil perangkingan ini, menjadi rekomendasi untuk pihak perusahaan dalam penentuan calon tenaga kerja yang akan diterima.

Kata Kunci-sistem pendukung keputusan, seleksi tenaga kerja, simple additive weighting, web.

\section{Pendahuluan}

Kemajuan sebuah perusahaan tak terlepas dari peranan

Mahasiswa Jurusan Teknik Elektro dan Komputer Fakultas Teknik, Universitas Udayana, Jln. Kampus Bukit Jimbaran 80361 INDONESIA (e-mail: ardifermanta@gmail.com)

${ }^{2,3}$ Dosen Jurusan Teknik Elektro dan Komputer Fakultas Teknik Universitas Udayana, Jln. Kampus Bukit Jimbaran 80361 INDONESIA (telp/fax: 0361-703315; e-mail: arsa.suyadnya@ unud.ac.id,dewi.wirastuti@unud.ac.id)

M. A. Fermanta: Rancang Bangun Sistem Pendukung ... tenaga kerja yang baik dan berkualitas sehingga perusahaan akan melakukan seleksi dan merekrut tenaga kerja yang memiliki kriteria sesuai dengan kebutuhan perusahaan. PT. Solusi Lintas Data Cabang Bali adalah sebuah perusahaan yang bergerak dalam bidang jasa penyedia layanan internet, dimana peranan tenaga kerja yang berkualitas terutama dalam bidang teknologi informasi akan sangat mempengaruhi masa depan perusahaan.

Pada PT. Solusi Lintas Data Cabang Bali, proses seleksi untuk calon tenaga kerja masih menerapkan metode konvensional dan tidak dilakukan secara komputerisasi. Hal ini menyebabkan proses seleksi penerimaan tenaga kerja membutuhkan waktu yang cukup lama mengingat banyaknya jumlah pelamar. Salah satu cara untuk mengatasi permasalahan tersebut adalah dengan membangun suatu sistem pendukung keputusan yang bisa membantu perusahaan dalam proses seleksi dan memutuskan karyawan yang dapat diterima bekerja pada perusahaan serta menyimpan data pelamar secara komputerisasi.

Penerapan atau penggunaan sistem pendukung keputusan telah banyak dilakukan. Adapun beberapa penelitian yang telah dilakukan sebelumnya mengenai sistem pendukung keputusan diantaranya sistem pendukung keputusan penerimaan tenaga kerja pada PT Yodya Karya Semarang dengan menerapkan metode Simple Additive Weighting [1] dan sistem pendukung keputusan untuk penentuan penerima beasiswa diklat dengan Fuzzy MADM (Multiple Attribute Decision Making) [2]. Penelitian pada PT Yodya Karya Semarang dengan metode Simple Additive Weighting, sistem yang dibangun berbasis web menggunakan bahasa pemrograman PHP dan database MySQL. Pada penelitian tersebut, data hasil tes dimasukan secara manual dan pendaftaran pelamar tidak dilakukan secara online karena aplikasi berjalan pada area intranet perusahaan. Aplikasi ini menghasilkan output berupa laporan penilaian kesesuaian pelamar berdasarkan tingkat kriteria yang ada. Selanjutnya, pada sistem pendukung keputusan untuk penentuan penerima beasiswa diklat dengan Fuzzy MADM, sistem yang dibangun juga berbasis web dimana data pemohon beasiswa dimasukkan secara manual oleh petugas ke dalam sistem. Metode Fuzzy MADM yang digunakan adalah metode Simple Additive Weighting. Seluruh data pemohon yang telah dimasukkan ke dalam sistem, selanjutnya diproses oleh sistem untuk menentukan penerima beasiswa berdasarkan hasil perangkingan pemohon beasiswa.

p-ISSN:1693 - 2951; e-ISSN: 2503-2372 
Metode Simple Additive Weighting (SAW) merupakan salah satu metode dalam sistem pendukung keputusan yang banyak digunakan. Metode SAW sering dikenal sebagai metode penjumlahan terbobot. Konsep dasarnya adalah mencari penjumlahan terbobot dari rating kinerja pada setiap alternatif pada semua atribut [3]. Metode SAW dapat membantu dalam pengambilan keputusan suatu kasus, dengan menghasilkan nilai terbesar yang akan terpilih sebagai alternatif terbaik. Perhitungan akan sesuai jika alternatif yang terpilih memenuhi kriteria yang telah ditentukan. Perhitungan dengan menggunakan metode SAW menjadi lebih efisien karena waktu yang dibutuhkan dalam perhitungan lebih singkat.

Berdasarkan permasalahan yang ada, maka dalam penelitian ini akan dirancang sebuah aplikasi sistem pendukung keputusan berbasis web dengan metode SAW untuk mendukung proses seleksi tenaga kerja pada PT. Solusi Lintas Data Cabang Bali. Dalam aplikasi yang dibangun, pelamar terlebih dahulu harus melakukan pendaftaran secara online, baru selanjutnya dapat mengikuti tahapan seleksi calon tenaga kerja.

\section{TinjauAn PUSTAKA}

\section{A. Seleksi Tenaga Kerja}

Seleksi tenaga kerja merupakan sebuah rangkaian tahaptahap khusus yang digunakan untuk menentukan calon tenaga kerja yang akan diterima bekerja dalam perusahaan. Dalam hal ini, telah ada sejumlah pelamar yang memenuhi persyaratan untuk selanjutnya dapat dipilih dan ditetapkan sebagai pegawai atau karyawan. Penerimaan akhir tenaga kerja dilakukan oleh departemen SDM sebagai hasil evaluasi terhadap proses seleksi tenaga kerja yang telah dilakukan dan tentunya melalui penggunaan prosedur-prosedur yang valid [4].

\section{B. Sistem Pendukung Keputusan}

Sistem pendukung keputusan atau dikenal dengan DSS (Decision Support System) adalah sebuah sistem informasi interaktif yang mampu menyediakan informasi, pemodelan dan pemanipulasian data. Sistem ini dapat digunakan untuk membantu pengambilan keputusan dalam situasi yang semiterstruktur dan situasi yang tidak terstruktur, dimana tak diketahui secara pasti bagaimana seharusnya keputusan tersebut dibuat. Sistem pendukung keputusan biasanya dibangun untuk mendukung pemecahan atas suatu permasalahan atau untuk melakukan evaluasi terhadap suatu peluang. Aplikasi sistem pendukung keputusan biasanya dibangun berbasis komputer yang fleksibel, interaktif, dan dapat diadaptasi untuk mendukung pemecahan atas masalah manajemen yang spesifik yang tidak terstruktur. Sistem pendukung keputusan tidak bertujuan untuk melakukan otomatisasi dalam pengambilan suatu keputusan, akan tetapi memberikan suatu perangkat yang interaktif sehingga memungkinkan pengambil keputusan untuk mengambil beberapa analisis menggunakan model-model yang ada [5].

\section{Simple Additive Weighting (SAW)}

Metode Simple Additive Weighting (SAW) dikenal juga dengan istilah metode penjumlahan terbobot. Metode SAW membutuhkan suatu proses normalisasi terhadap matriks keputusan (x) ke suatu skala yang bisa diperbandingkan dengan semua rating alternatif yang ada (1). Dalam metode Simple Additive Weighting diharuskan untuk melakukan penentuan bobot dari setiap atribut. Nilai total dari alternatif dapat dihasilkan dengan melakukan penjumlahan seluruh hasil perkalian yang dilakukan antara rating (yang dapat dibandingkan lintas atribut) dan bobot pada setiap atribut (2).

$r_{i j}= \begin{cases}\frac{x_{i j}}{\operatorname{Max}_{i}\left(x_{i j}\right)} & \begin{array}{l}\text { Jika j adalah atribut keuntungan } \\ \text { (benefit) }\end{array} \\ \frac{\operatorname{Min}_{i}\left(x_{i j}\right)}{x_{i j}} & \text { Jika j adalah atribut biaya (cost) }\end{cases}$

Dimana :

$r_{i j}=$ rating kinerja yang ternormalisasi

$\operatorname{Max}_{i}\left(x_{i j}\right)=$ nilai maksimum yang ada dari setiap baris dan kolom

$\operatorname{Min}_{i}\left(x_{i j}\right)=$ nilai minimum yang ada dari setiap baris dan kolom

$x_{i j}=$ baris dan kolom dari matriks

Dengan $r_{i j}$ merupakan rating kinerja yang ternormalisasi dari alternatif $A_{i}$ yang ada pada atribut kriteria $C_{j} ; \mathrm{i}=1,2, \ldots \mathrm{m}$ dan $j$ $=1,2, \ldots, n$. Selanjutnya untuk nilai preferensi pada setiap alternatif $(\mathrm{Vi})$ diberikan sebagai:

$$
V_{i}=\sum_{j=1}^{n} w_{j} r_{i j}
$$

Dimana :

$V_{i}=$ Nilai akhir dari alternatif yang ada

$w_{j}=$ Nilai bobot yang telah ditetapkan

$r_{i j}=$ Normalisasi matriks

Dengan membandingkan hasil perhitungan nilai $V_{i}$, dimana nilai $V_{i}$ yang lebih besar maka mengindikasikan bahwa alternatif $A_{i}$ menjadi lebih terpilih dibandingkan alternatif lainnya [3].

\section{PHP (PHP Hypertext Preprocessor)}

PHP merupakan scripting language yang diletakkan pada sisi server dan selanjutnya diproses di sisi server oleh sebuah mesin PHP. Hasil pemrosesan tersebut selanjutnya dikirim ke client, dimana client menggunakan browser. PHP dirancang untuk membangun suatu web yang tidak statis dalam hal konten atau dikenal dengan istilah web dinamis. Dalam hal ini, PHP dapat menghasilkan suatu tampilan berdasarkan permintaan terkini yakni dengan memproses permintaan ke database server kemudian menampilkan isi database ke halaman web. Seluruh hasil pemrosesan yang dilakukan tersebut akan dikirimkan ke sisi client dalam bentuk dokumen HTML (HyperText Markup Language). HTML merupakan 
bahasa standar yang digunakan untuk membuat halamanhalaman web [6].

\section{METODE PENELITIAN}

\section{A. Tahapan Penelitian}

Adapun tahapan-tahapan penelitian yang dilakukan adalah sebagai berikut.

1. Pendefinisian terhadap permasalahan dari sistem seleksi tenaga kerja yang akan dibangun.

2. Pemahaman terhadap proses-proses yang ada dalam sistem seleksi tenaga kerja sehingga dapat dilakukan pemodelan sistem

3. Perancangan database dan rancangan tampilan antarmuka

4. Pemrograman atau coding untuk membangun sistem sesuai hasil dari pemodelan sistem

5. Pengujian terhadap sistem dan melakukan analisis hasil pengujian sistem

6. Pengambilan kesimpulan dan pembuatan laporan

\section{B. Analisis Data Dengan Metode SAW}

Konsep dasar dari metode SAW adalah melakukan pencarian terhadap penjumlahan terbobot dari rating kinerja pada setiap alternatif yang ada dalam semua atribut. Metode SAW dapat digunakan untuk membantu pengambilan keputusan karena dalam metode ini dilakukan penentuan nilai bobot untuk setiap atribut, yang selanjutya dilakukan proses perangkingan. Dalam proses perankingan akan ditentukan alternatif terbaik dari sejumlah alternatif yang tersedia.

Terdapat beberapa kriteria dalam menentukan lulus atau tidaknya para pelamar pada saat menghadapi serangkaian tes. Serangkaian tes yang dilakukan memiliki bobot nilai yang ditentukan oleh PT Solusi Lintas Data Cabang Bali. Kriteria dan bobot penilaian tersebut yaitu:

a) Untuk tes administrasi kriteria minimal:

1. Umur $=$ Maksimal 27 tahun (diatas 27 tahun tidak lulus)

2. Pendidikan terakhir (bobot: $30 \%$ )

$\begin{array}{ll}\text { S1 } & : 75 \\ \text { D2/D3 } & : 65\end{array}$

D1/SMK/SMA : 55

3. Jurusan (bobot: 20\%)

$\begin{array}{lll}\text { IPA } & & : 60 \\ \text { TKJ } & & : 70 \\ \text { Elektro } & & : 80 \\ \text { Komputer } & & : 80 \\ \text { Other } & : 50 & \end{array}$

4. Pengalaman bekerja (bobot: $20 \%$ )
Ada
$: 70$

Tidak

$: 40$

5. Posisi (bobot: $20 \%$ )

Berhubungan dengan teknik komputer : 70

Tidak berhubungan dengan teknik komputer : 40

6. Lama bekerja (bobot: $10 \%$ )
$1-12$ bulan
$: 60$
1-3 tahun
$: 80$
Di atas 3 tahun
$: 95$

b) Untuk tes psikologi, minimal nilai yang harus diperoleh adalah 50

M. A. Fermanta: Rancang Bangun Sistem Pendukung ... c) Untuk tes wawancara, minimal nilai yang harus diperoleh adalah 50

Berikut ini pada Tabel 1 ditampilkan contoh kasus penerimaan tenaga kerja dengan kriteria dan alternatif yang ada.

TABEL I

Contoh Kasus Penerimaan Tenaga KerJa Dengan Kriteria DAN ALTERNATIF

\begin{tabular}{|c|c|c|c|c|c|c|c|c|}
\hline \multirow{2}{*}{\multicolumn{2}{|c|}{ Kriteria }} & \multirow[b]{2}{*}{ Bobot } & \multicolumn{6}{|c|}{ Alternatif } \\
\hline & & & $\begin{array}{c}\text { Pelamar } \\
1\end{array}$ & $\begin{array}{c}\text { Pelamar } \\
2 \\
\end{array}$ & $\begin{array}{c}\text { Pelamar } \\
3\end{array}$ & $\begin{array}{c}\text { Pelamar } \\
4\end{array}$ & $\begin{array}{c}\text { Pelamar } \\
5\end{array}$ & $\begin{array}{c}\text { Pelamar } \\
6\end{array}$ \\
\hline \multicolumn{2}{|c|}{ Administrasi } & \multirow{6}{*}{$50 \%$} & & & & & & \\
\hline $30 \%$ & $\begin{array}{l}\text { Pendidikan } \\
\text { Terakhir } \\
\end{array}$ & & 55 & 55 & 55 & 65 & 75 & 65 \\
\hline $20 \%$ & $\begin{array}{l}\text { Jurusan } \\
\text { Pendidikan }\end{array}$ & & 60 & 70 & 50 & 80 & 50 & 80 \\
\hline $20 \%$ & $\begin{array}{l}\text { Pengalaman } \\
\text { Kerja }\end{array}$ & & 70 & 70 & 70 & 40 & 70 & 40 \\
\hline $20 \%$ & Posisi Bekerja & & 70 & 70 & 70 & 0 & 0 & 0 \\
\hline $10 \%$ & Lama Bekerja & & 60 & 60 & 60 & 0 & 0 & 0 \\
\hline \multicolumn{2}{|c|}{ Psikologi } & $30 \%$ & 50 & 50 & 50 & 75 & 90 & 75 \\
\hline \multicolumn{2}{|c|}{ Wawancara } & $20 \%$ & 50 & 55 & 50 & 70 & 80 & 65 \\
\hline
\end{tabular}

Dari data pada Tabel 1, kemudian dilakukan perhitungan alternatif pada kriteria sehingga diperoleh hasil perhitungan seperti pada Tabel 2 .

TABEL II

HASIl PERhitungan Alternatif PADA KRITERIA

\begin{tabular}{|l|c|c|c|c|c|c|}
\hline \multirow{2}{*}{ Kriteria } & \multicolumn{6}{|c|}{ Alternatif } \\
\cline { 2 - 7 } & Pelamar 1 & Pelamar 2 & Pelamar 3 & Pelamar 4 & Pelamar 5 & Pelamar 6 \\
\hline $\begin{array}{l}\text { Administrasi } \\
(50 \%)\end{array}$ & 62,5 & 64,5 & 60,5 & 43,5 & 46,5 & 43,5 \\
\hline Psikologi (30\%) & 50 & 55 & 60 & 75 & 90 & 75 \\
\hline $\begin{array}{l}\text { Wawancara } \\
(20 \%)\end{array}$ & 50 & 55 & 50 & 70 & 80 & 65 \\
\hline
\end{tabular}

Setelah hasil dari masing-masing tes diketahui, maka dilakukan normalisasi.

$$
\begin{aligned}
& r 11=\frac{62,5}{\max \{62,5 ; 64,5 ; 60,5 ; 43,5 ; 46,5 ; 43,5\}}=\frac{62,5}{64,5}=0,97 \\
& r 12=\frac{64,5}{\max \{62,5 ; 64,5 ; 60,5 ; 43,5 ; 46,5 ; 43,5\}}=\frac{64,5}{64,5}=1 \\
& r 21=\frac{50}{\max \{50 ; 50 ; 50 ; 75 ; 90 ; 75\}}=\frac{50}{90}=0,56 \\
& r 22=\frac{55}{\max \{50 ; 50 ; 50 ; 75 ; 90 ; 75\}}=\frac{55}{90}=0,61
\end{aligned}
$$

dan seterusnya, sehingga diperoleh matrik normalisasi sebagai berikut.

$$
R=\left[\begin{array}{llllll}
0,97 & 1,00 & 0,93 & 0,66 & 0,69 & 0,66 \\
0,56 & 0,61 & 0,67 & 0,83 & 1,00 & 0,83 \\
0,63 & 0,69 & 0,63 & 0,88 & 1,00 & 0,81
\end{array}\right]
$$

Pada proses perangkingan, nilai bobot yang telah ditentukan adalah $\mathrm{w}=(0.50,0.30,0.20)$. Berikut ini adalah perkalian hasil normalisasi dengan bobot yang telah diberikan:

$$
\begin{aligned}
& \mathrm{V}_{1}=(0,50 \times 0,97)+(0,30 \times 0,56)+(0,20 \times 0,63)=0,774 \\
& \mathrm{~V}_{2}=(0,50 \times 1,00)+(0,30 \times 0,61)+(0,20 \times 0,69)=0,821 \\
& \mathrm{~V}_{3}=(0,50 \times 0,93)+(0,30 \times 0,67)+(0,20 \times 0,63)=0,789 \\
& \mathrm{~V}_{4}=(0,50 \times 0,66)+(0,30 \times 0,83)+(0,20 \times 0,88)=0,753 \\
& \mathrm{~V}_{5}=(0,50 \times 0,69)+(0,30 \times 1,00)+(0,20 \times 1,00)=0,846
\end{aligned}
$$

p-ISSN:1693 - 2951; e-ISSN: 2503-2372 
$\mathrm{V}_{6}=(0,50 \times 0,66)+(0,30 \times 0,83)+(0,20 \times 0,81)=0,741$

Nilai terbesar diperoleh pada $\mathrm{V}_{5}$, sehingga alternatif pelamar 5 menjadi alternatif terbaik. Berikut Tabel 3 adalah tabel perangkingan dari perhitungan dengan menggunakan metode SAW.

TABEL III

Hasil Perhitungan Dan Perangkingan Dengan Metode SAW

\begin{tabular}{|l|c|c|c|c|c|c|}
\hline \multirow{2}{*}{ Kriteria } & \multicolumn{5}{|c|}{ Altematif } \\
\cline { 2 - 7 } & Pelamar 1 & Pelamar 2 & Pelamar 3 & Pelamar 4 & Pelamar 5 & Pelamar 6 \\
\hline $\begin{array}{l}\text { Administrasi } \\
(50 \%)\end{array}$ & 62,5 & 64,5 & 60,5 & 43,5 & 46,5 & 43,5 \\
\hline $\begin{array}{l}\text { Psikologi } \\
(30 \%)\end{array}$ & 50 & 55 & 60 & 75 & 90 & 75 \\
\hline $\begin{array}{l}\text { Wawancara } \\
(20 \%)\end{array}$ & 50 & 55 & 50 & 70 & 80 & 65 \\
\hline $\begin{array}{l}\text { Penghitungan } \\
\text { SAW }\end{array}$ & 0,774 & 0,821 & 0,789 & 0,753 & 0,846 & 0,741 \\
\hline Rangking & 4 & 2 & 3 & 5 & 1 & 6 \\
\hline
\end{tabular}

\section{Diagram Konteks}

Diagram konteks atau context diagram merupakan diagram yang menggambarkan ruang lingkup suatu sistem, seperti terlihat pada Gambar 1. Context diagram tersebut menggambarkan proses secara umum yang terjadi pada proses seleksi tenaga kerja. Dalam context diagram tersebut, juga terlihat bahwa sistem pendukung keputusan seleksi tenaga kerja melibatkan 4 entitas luar yaitu pelamar, lembaga psikologi, HRD, dan pimpinan.

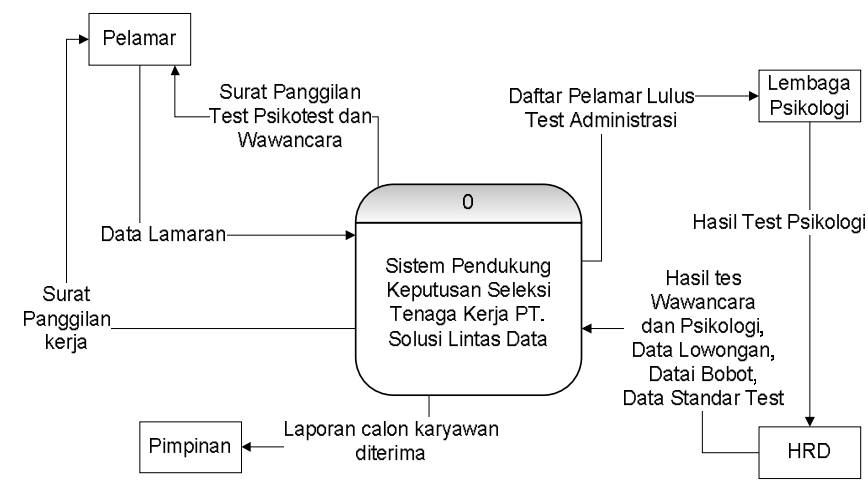

Gambar 1: Context diagram

\section{Perancangan Database}

Perancangan database, ditunjukkan dengan diagram relasi antar tabel. Diagram relasi antar tabel merupakan diagram yang berfungsi untuk menampilkan hubungan antar tabel yang berbeda dalam database. Berikut ini pada Gambar 2 merupakan diagram relasi antar tabel dalam database sistem.

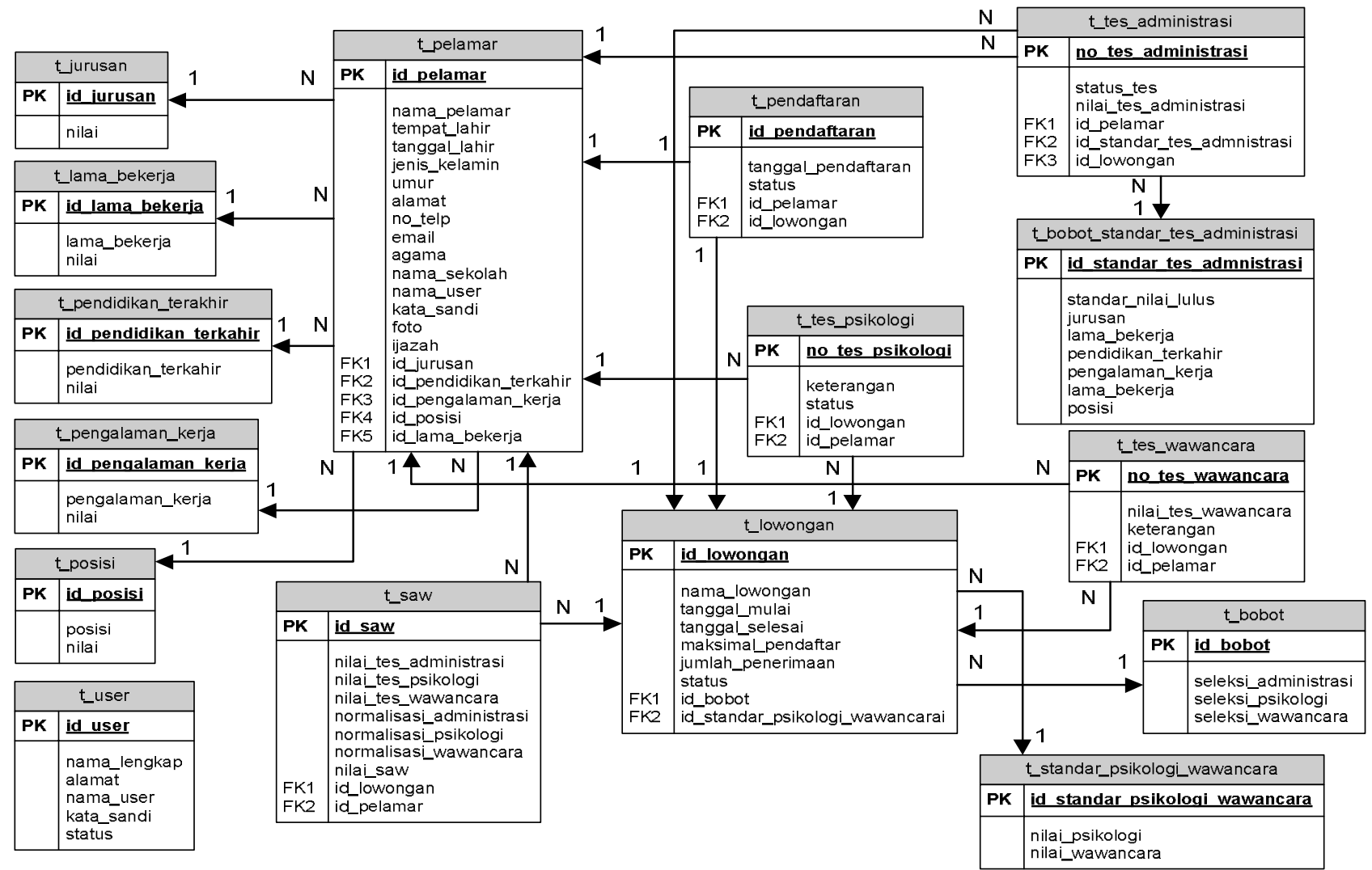

Gambar 2: Relasi antar tabel 


\section{HASIL DAN PEMBAHASAN}

Penelitian ini menghasilkan sebuah sistem pendukung keputusan berbasis web untuk melakukan seleksi tenaga kerja. yang menerapkan Metode Simple Additive Weighting. Sistem pendukung keputusan ini dibangun menggunakan bahasa pemrograman web PHP dan database yang digunakan adalah MySQL. Dalam proses penerimaan tenaga kerja, calon tenaga kerja akan melakukan tiga tahapan seleksi. Masingmasing seleksi mempunyai nilai standar yang ditetapkan oleh bagian HRD perusahaan. Pelamar yang sudah mendaftar akan mengikuti tahapan seleksi dan hasil akhir dilakukan perangkingan dengan menggunakan metode SAW untuk memperoleh rekomendasi penerimaan calon tenaga kerja

Berikut ini akan dijelaskan proses penerimaan tenaga kerja pada PT Solusi Lintas Data Cabang Bali dengan menggunakan sistem pendukung keputusan.

\section{A. Pembuatan Lowongan}

Dalam Pembuatan Lowongan terlebih dahulu harus menentukan masing masing bobot yang akan digunakan untuk melakukan seleksi, diantaranya yaitu bobot SAW dan standar nilai dari masing masing tes. Dalam menentukan bobot sebuah lowongan harus dengan persetujuan dari divisi yang memerlukan tenaga kerja dan persetujuan pihak manajemen. Penambahan data lowongan dilakukan melalui menu lowongan yang dapat diakses oleh pihak HRD yang berstatus sebagai admin. Berikut ini pada Gambar 3 merupakan tampilan form data lowongan kerja.

\begin{tabular}{|l|}
\hline Beranda / Lowongan / Edit \\
\hline Edit Lowongan Kerja \\
ID Lowongan \\
\hline 1 \\
\hline Nama Lowongan Kerja \\
\hline Support \\
Tanggal Mulai \\
\hline $2015-07-27$ \\
Tanggal Berakhir \\
\hline $2015-07-30$ \\
\hline ID Bobot \\
\hline SAW001 \\
\hline ID Standar Nilai Lulus \\
\hline SNL001 \\
\hline Jumlah Penerimaaan \\
\hline 1 \\
\hline
\end{tabular}

\section{B. Proses Melamar Kerja}

Proses melamar kerja, diawali dengan pelamar melihat lowongan kerja yang tersedia web PT Solusi Lintas Data Cabang Bali seperti pada Gambar 4. Setelah melakukan klik pada tombol daftar maka pelamar akan diarahkan ke halaman login untuk melakukan proses login dengan memasukkan data login bagi pelamar yang sebelumnya pernah mendaftar. Apabila pelamar belum pernah mendaftar pada sistem maka dapat melakukan pendaftaran dengan menekan tombol Mendaftar Pelamar seperti terlihat pada Gambar 5.

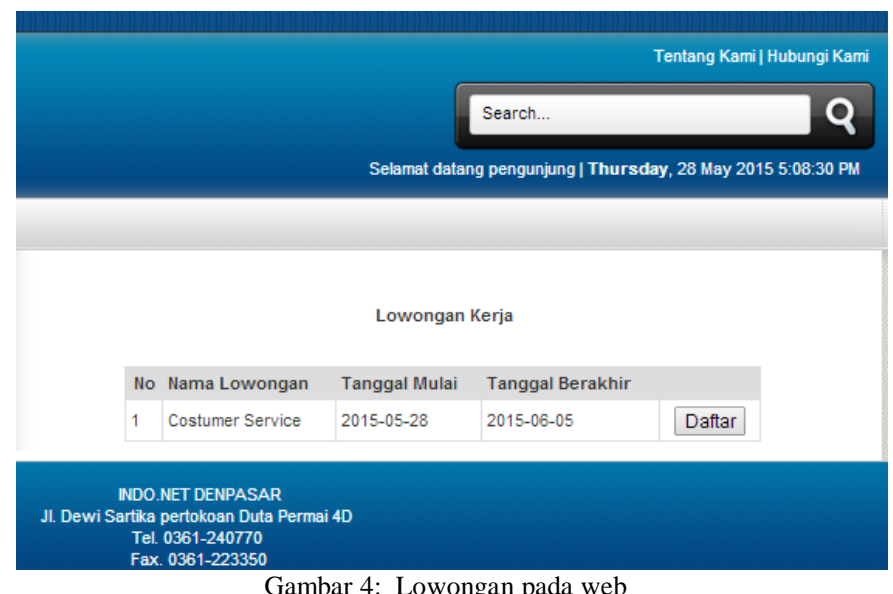

Gambar 4: Lowongan pada web

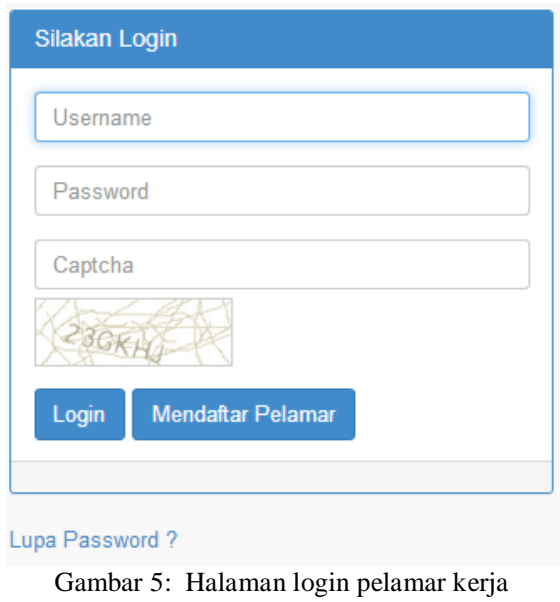

Setelah pelamar berhasil login ke dalam sistem, pelamar dapat melengkapi data pelamar dengan memilih menu Profil Saya dan Upload Data seperti terlihat pada Gambar 6. Pada bagian tersebut pelamar dapat mengisi biodata, menambahkan hasil scan ijasah dan foto pelamar.

$$
\begin{aligned}
& \text { Beranda } \\
& \text { 四 Lihat Lowongan } \\
& \square \text { Profil Saya } \\
& \text { ․ Upload Data }
\end{aligned}
$$

Gambar 6: Menu sistem untuk pelamar kerja

Selanjutnya, melalui menu lihat lowongan pelamar dapat melakukan pendaftaran terhadap lowongan yang tersedia dengan menekan tombol Daftar, seperti pada Gambar 7.

p-ISSN:1693 - 2951; e-ISSN: 2503-2372

M. A. Fermanta: Rancang Bangun Sistem Pendukung ... 


\begin{tabular}{|l|l|l|l|}
\hline Tanggal Mulai & Tanggal Berakhir & Nama Lowongan & Aksi \\
\hline $2015-04-09$ & $2015-04-18$ & SUPPORT & Daffar \\
\hline
\end{tabular}

\section{Seleksi Calon Tenaga Kerja}

Pada tahapan ini, pelamar akan melewati beberapa tahapan tes/seleksi. Seleksi administrasi merupakan seleksi awal yang dilakukan kepada pelamar. Dalam seleksi ini penilaian disesuaikan dengan standar tes administrasi, yaitu dalam hal pendidikan terakhir yang ditempuh, jurusan atau konsentrasi yang diambil saat menempuh pendidikan, pengalaman kerja, posisi dalam pengalaman kerja, dan lama bekerja pelamar sesuai pengalaman pelamar. Untuk memenuhi syarat kelulusan tes administrasi, pelamar diwajibkan membawa bukti asli dari biodata pelamar yang telah diinputkan pada sistem sebelumnya dan apabila ditemukan ketidakcocokan antara bukti asli dan data pelamar yang telah diinputkan dalam sistem maka pelamar dinyatakan tidak lulus.

Setelah dinyatakan lulus tes administrasi, pelamar akan melanjutkan ke tes selanjutnya yaitu tes psikologi. Pelamar akan diminta mengerjakan soal yang sudah disediakan oleh perusahaan. Nilai dari tes akan dimasukan ke sistem oleh admin dan akan diproses oleh sistem, seperti terlihat pada Gambar 8.

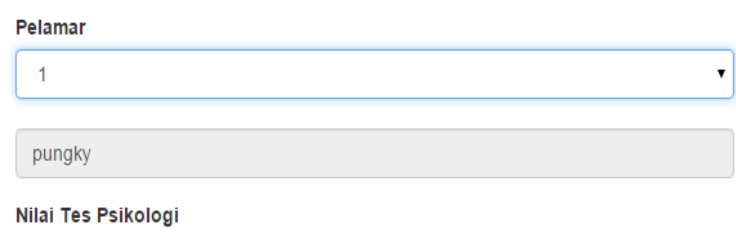

Gambar 8: Input nilai tes psikologi

Setelah dinyatakan lulus tes psikologi, pelamar akan melanjutkan ke tes selanjutnya yaitu tes wawancara. Nilai dari tes wawancara akan dimasukan ke sistem oleh admin dan akan diproses oleh sistem, seperti terlihat pada Gambar 9.

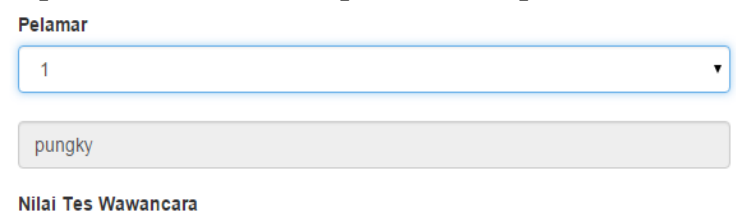

Nilai Tes Wawancara

Gambar 9: Input nilai tes wawancara

\section{Seleksi Menggunakan Metode SAW}

Para pelamar yang telah lulus dan melewati beberapa tahapan seleksi sebelumnya akan diseleksi kembali menggunakan metode SAW. Dari hasil seleksi tersebut seperti terlihat pada Gambar 10 maka akan diperoleh perangkingan dari pelamar. Pelamar dengan nilai tertinggi dan rangking teratas akan direkomendasikan untuk diterima bekerja pada perusahaan.

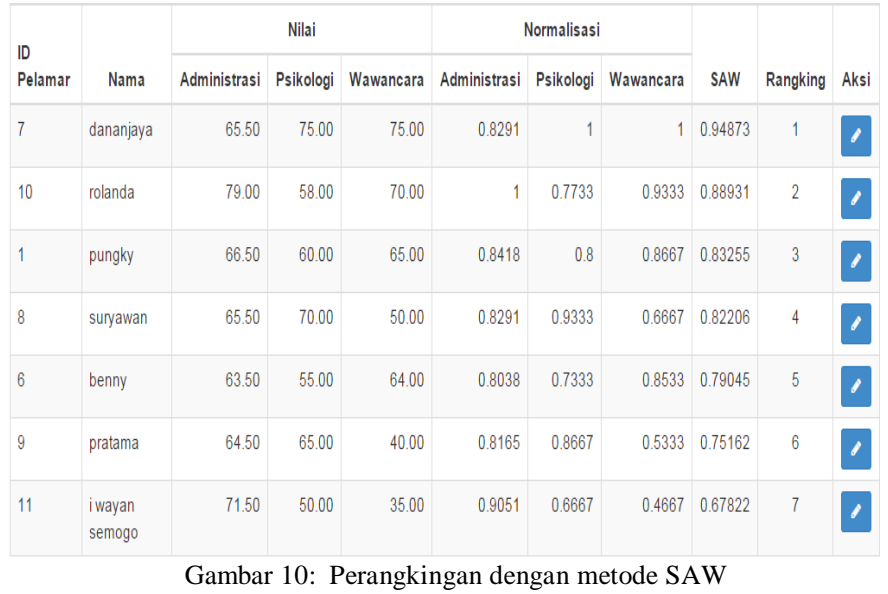

Untuk menanggulangi permasalahan jika terdapat pelamar yang mempunyai nilai sama dan memiliki rangking setara maka terdapat menu edit yang dapat digunakan admin untuk menentukan pelamar yang diterima bekerja seperti terlihat pada Gambar 11.

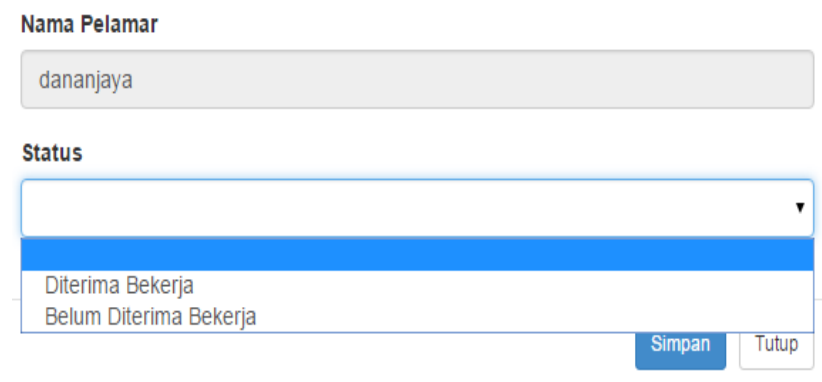

Gambar 11: Penentuan status penerimaan pelamar

\section{E. Pengumuman Hasil Seleksi}

Setelah pelamar dinyatakan lulus dari semua tes dan telah telah dilakukan perangkingan. Pihak perusahaan akan mengumumkan hasil penerimaan tenaga kerja melalui website PT. Solusi Lintas Data Cabang Bali. Pelamar dapat melihat hasil penerimaan tenaga kerja tersebut dengan cara mendownload file pengumuman yang telah disediakan perusahaan seperti terlihat pada Gambar 12.

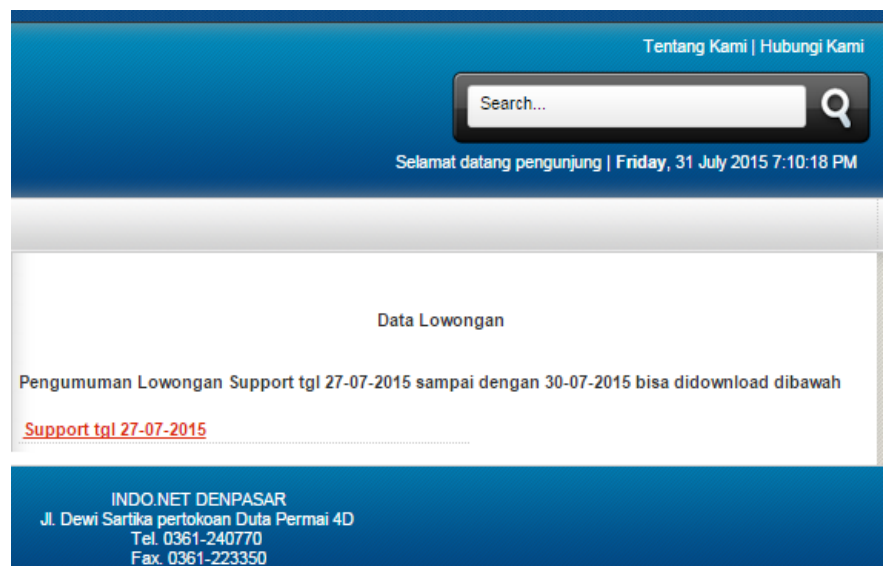

Gambar 12: Pengumuman hasil seleksi pada web perusahaan 


\section{KESIMPULAN}

Sistem pendukung keputusan berbasis web untuk seleksi tenaga kerja pada PT Solusi Lintas Data Cabang Bali telah berhasil dibangun dengan menerapkan metode Simple Additive Weighting (SAW). Adanya sistem pendukung keputusan ini, menyebabkan waktu yang dibutuhkan dalam proses seleksi penerimaan tenaga kerja menjadi lebih cepat. Metode SAW yang digunakan mampu memberikan penilaian secara lebih tepat karena perhitungan yang dilakukan berdasarkan pada nilai-nilai kriteria dan bobot yang telah ditentukan. Kriteria yang digunakan dalam seleksi calon tenaga kerja, yakni seleksi administrasi, psikologi dan wawancara. Secara umum proses dalam seleksi tenaga kerja dalam penelitian ini terdiri dari beberapa tahapan yaitu: pembuatan lowongan yang dibutuhkan perusahaan, pendaftaran pelamar secara online, seleksi pelamar, perangkingan pelamar oleh sistem dengan menggunakan metode SAW, dan penentuan calon tenaga kerja yang diterima. Hasil dari proses sistem menggunakan metode SAW adalah perangkingan dari pelamar dengan rangking tertinggi sampai dengan rangking terendah. Hasil perangkingan ini, menjadi rekomendasi untuk pihak perusahaan dalam penentuan calon tenaga kerja yang akan diterima.

\section{REFERENSI}

[1] J. M. S. Putra, "Sistem Pendukung Keputusan Penerimaan Karyawan PT. Yodya Karya (Persero) Semarang dengan Fuzzy Multiple Attribute Decision Making Metode Simple Additive Weighting" (tugas akhir). Semarang: Universitas Dian Nuswantoro, 2013.

[2] Tri Handayani, Wawan Laksito Y. S., dan Teguh Susyanto. "Sistem Pendukung Keputusan Beasiswa Diklat Dengan Fuzzy MADM", Jurnal Ilmiah Teknologi Informasi dan Komunikasi, Vol. 1 No. 2, Hal. 29-34, Oktober 2013.

[3] Sri Kusumadewi, Fuzzy Multi Attribute Decision Making.Yogyakarta: Graha Ilmu, 2006.

[4] G.F. Adnyana, "Rancang Bangun Sistem Pendukung Keputusan Seleksi Tenaga Kerja Dengan Menggunakan Metode Promethee (Studi Kasus PT. Telkomsel Regional Bali - Nusa Tenggara)" (tugas akhir). Surabaya: Sekolah Tinggi Manajemen Informatika dan Teknik Komputer, 2012.

[5] E. Turban, Decision Support System and Intelligent Systems. Yogyakarta: Andi, 2005.

[6] A. Kadir. Dasar Pemrograman Web Dinamis Menggunakan PHP. Yogyakarta: Penerbit Andi, 2008. 
[ Halaman ini sengaja di kosongkan] 